\title{
OPTIMIZATION OF INVESTMENT STRATEGY FOR THE ACQUISITION OF MEANS OF MECHANIZATION
}

Jozef REPISKÝ, Faculty of Economics and Management, Slovak University of Agriculture in Nitra, Trieda Andreja Hlinku 2, 94976 Nitra, Slovak Republic jozef.repisky@uniag.sk

The aim of the paper is to identify the optimal investment strategy of acquiring the means of mechanization of an agricultural enterprise. A suitable mean to meet the goal is the application of a multiperiodic optimization model, which is designed in the spreadsheet program Excel (including Solver). Objective function is represented by property maximization at the end of considered period via Net present value. The set of restrictive conditions is represented by the balance of production and financial factors, the balance of cost and production indicators, production and credit restrictions, as well as the conditions of securing the company's liquidity in each time period through positive cumulative cash flow and sufficient financial resources to cover capital investment and working capital. The comparison of NPV values of individual variants of optimization models documents the logical consequences of the gradual optimization of plant and animal production, the time of acquisition of mechanization means without and with the limitation of credit resources and the time of loan repayment. The most suitable solution, with additional restrictive conditions for limited credit resources of up to $€ 50,000$ per year, an interest rate of $6 \%$ and a repayment period of up to 7 years, is to procure a Vogel-nootHektor plow in the first year, Horch Pronto seed drills in the second, fertilizer spreaders Rauch in the third, a Fendt combine with a rape cutter and a pea straw crusher in the fourth year and a corn header in the fifth year. The resulting value of NPV represents the amount of $€ 343,922$, while the required amount of credit resources in the first year is $€ 42,595$ with a repayment period of 4 years, in the second year $€ 31,079$ with a repayment of 3 years and in the fourth year $€ 48,284$ with a repayment period of 7 years.

Keywords: multi-periodic optimization model, investment project, acquisition of means of mechanization, net present value

\section{INTRODUCTION}

From the point of view of the success of an economic entity, investment decisions in the area of substantive decisionmaking have a decisive mission. Modelling technology can significantly help to improve this activity, especially in the creation and evaluation of investment plans. One of the key issues for any business entity is identification of an appropriate procurement strategy, whether in terms of different types of technology or acquisition time, which is constrained by financial resources. From this point of view, the aim of the paper is to identify the optimal investment strategy of acquiring the means of mechanization of an agricultural enterprise using a multiperiodic optimization model. Objective function is represented by Net present value. Authors like Kasaš et al. (2011) show that for process flow sheet optimization only net present value is a correct criterion as the objective function, while selecting among mutually exclusive alternatives. With sufficient levels of accuracy, those process models are suitable for generating proper optimal designs.

Linear programming with NPV as objective function, used in this work, have been used for several studies f. e. in identification optimal forest age structure and rotation age strategy (Baskent at al., 2011) and in finding a solution that takes into account soil conservation, water production and timber production in forest management planning (Karahalil et al., 2011). The application of linear programming and fuzzy optimization in the field of tangible assets acquisition within the company can be found in the article from Bolos et al. (2020). Authors Khan, Asad (2020) propose a new mixed integer linear programming based model that maximises NPV subject to the mining, processing, refining capacity constraints and develops an optimal cut-off grade policy for an open pit mining operation with multiple processing streams.

Applications of model techniques in investment decision-making also with risk taken into consideration via a simulation model can be found in the articles in different fields: like in agriculture: Repiský (2006), Repiský (2019), or in co - generation plants: Colantoni at al. (2021), as well as in gold mining: Franco - Sepulveda at al. (2017), or in privately financed road projects: Bagui, Ghosh (2012).

\section{RESEARCH METHODS}

The construction of an investment plan model consists of certain steps that are necessary regardless of the type of investment, scope, or material aspect. It is necessary to define the system on the investigated economic reality, define the 
elements of the system and their links, perform the construction of the model and its quantification, select a suitable method of solution, interpret and analyse the obtained solutions and then use them in the implementation phase.

The most important parts of the construction and quantification of the model are the definition of variables (decisionmaking, exogenous, strategic, limiting, etc.) and the estimation of production and project costs. The model itself consists of the following parts: cost estimation: capital, variable, fixed, working capital, estimation of production, depreciation, financing of the investment, loan, repayment calendar, projected profit and loss statement, cash flow statement and balance sheet statement.

The presented multi-period optimization model simulating a ten-year period of an agricultural business entity is created in an Excel spreadsheet. It enables the optimization of the production structure, the optimization of the time of acquisition of mechanization means, as well as the optimal financing of the investment. The strategic goal is represented by the objective function of maximizing the assets of the business entity in the form of the indicator net present value (NPV) for the life of the investment.

$$
N P V=\sum_{t=0}^{n} C F_{t} \frac{1}{(1+i)^{t}}-I_{0}
$$

where: NPV - Net Present Value,

$\mathrm{CF}_{\mathrm{t}}$ - Cash Flow from investment in each year of its lifespan $\mathrm{t}$,

$\mathrm{I}$ - discount rate (in \% / 100),

$\mathrm{N}$ - lifetime of the investment,

$\mathrm{I}_{0}$ - initial capital expenditure.

This method is described in detail e.g. by Northcott (1992), Lumby (1996), Xu (2015), Hopkinson (2016). Authors like Žižlavský (2014) investigate pros and cons of net present value and discusses methods able to deal with NPV weaknesses. The suitability of the NPV method in investment decisions is also documented in Marchioni (2018). The analysis based on the sensitivity analysis, confirms that the reliability of metrics, that is a function of the vector of value factors, depends on its compatibility with the NPV. Similarly, Nuryanah (2017) documents that it is appropriate to use a discounted cash flow valuation model using an optimization approach as a business model for measuring the value of companies to achieve Good Corporate Governance.

Investment projects with a positive net present value are acceptable to the company, because the amount of cash expenditures over the life of the established investment must ensure payment of funds spent, ensure the required rate of return, expressed at a discount rate, and should increase cash flow and thus contribute to market growth of the company values. NPV is the only technique by which we obtain a decision leading to the maximization of the owner's assets.

\section{RESEARCH RESULTS}

The model solution of the investment plan for the acquisition of mechanization means enables changes in decisions in the areas of:

- structure and scope of production,

- obtaining of investment funds (time and material aspect),

- financing of investment,

- loan policy,

- depreciation policy. Decision variables of the model are:

$$
\begin{aligned}
& h_{h}^{t}, x_{k}^{t} \quad t=1,2, \ldots, n \\
& n \quad \text { investment lifetime } \\
& h \in N_{l} \quad \text { a set of plant production branches sowing crops harvested on owned land } \\
& k \in N_{2} \quad \text { a set of plant production branches sowing crops harvested on rented land } \\
& v^{t} \quad \text { required number of pig litters over time } \mathrm{t} \\
& m_{s}{ }^{t} \quad s \in N_{3} \quad \text { a set of purchased mechanical tools } \\
& o_{r, s}{ }^{t} \quad r \in N_{4} \quad \text { a set of depreciation ways of purchased mechanical tools } \\
& f_{p, s}{ }^{t} \quad p \in N_{5} \quad \text { a set of ways of financing investment } \\
& u_{q}{ }^{t} \quad q \in N_{6} \quad \text { a set of ways of loan repayment }
\end{aligned}
$$

Due to placement reasons, the mathematical formulation of the model will not be published in the paper, more emphasis will be placed on the factual side of the problem. The mathematical formulation of a similar model focused on vineyard planting is given in the article of Repiský (2019) The model solution is based on the construction of a multi-period balance model consisting of consecutive tables through which it is closer to the understanding of managers with economic education.

> Basic characteristics of company - planting and animal production. It provides basic information on the production activities of the company, which manages an area of 1,500 ha with the possibility of renting additional arable land. Crop production is focused on the cultivation of winter wheat, corn for grain, oilseed rape and peas. Animal production is focused on pig breeding. The user has the option of choosing the structure and scope of crop production, the amount of leased arable land, the amount of rent as well as the extent of pig breeding and some 
data on herd turnover (number of piglets born per litter, mortality rate, culling rate, number of sows purchased, etc.), on the basis of which the herd turnover is calculated.

$>$ Sales of plant and animal production. Potential production sales are calculated using estimated yields per hectare, the number of weaners sold and fattening pigs and the input prices of individual commodities entered. The contracting authority decides how much production will take place in the given year and how much will be left in the form of stocks for the next period.

$>$ Main characteristics of company - mechanization. It provides information on the state of mechanization means in the company. Based on its production and financial strategy, the user can choose which mechanization means to procure in a certain period of time, or which work to perform in the form of services and to what extent. The possibilities of different strategies for soil preparation and harvesting work, as well as different combination options of investment decisions in terms of price and performance of individual machines are listed in Table 1.

Table 1. Mechanization tools

\begin{tabular}{|c|c|c|c|c|c|c|}
\hline \multirow{2}{*}{\multicolumn{3}{|c|}{$\begin{array}{r}\text { Obtaining of mechanization tools } \\
\text { A) Mechanization tools for soil preparation and sowing }\end{array}$}} & \multicolumn{4}{|c|}{ Years } \\
\hline & & & 1. & 2. & 3. & 4. \\
\hline Soil preparation and sowing with plowing & Price in $€$ & $\begin{array}{c}\text { Yields } \\
\text { in ha.h }{ }^{-1}\end{array}$ & $\begin{array}{c}\text { Own } \\
\text { machine }\end{array}$ & $\begin{array}{c}\text { Own } \\
\text { machine }\end{array}$ & $\begin{array}{c}\text { Own } \\
\text { machine }\end{array}$ & $\begin{array}{c}\text { Own } \\
\text { machine }\end{array}$ \\
\hline Plow Vogel-nootHektor 10006 blade & 39000,00 & 1,20 & $\mathrm{y}$ & $\mathrm{n}$ & $\mathrm{n}$ & $\mathrm{n}$ \\
\hline Seeder HORSCH Pronto 6 DC & 83000,00 & 6,50 & $\mathrm{y}$ & $\mathrm{n}$ & $\mathrm{n}$ & $\mathrm{n}$ \\
\hline \multicolumn{3}{|l|}{ Soil preparation and sowing without plowing } & -------- & ------- & ------- & ------- \\
\hline Cultivator HORSCH - Tiger 3 MT & 44000,00 & 2,80 & $\mathrm{n}$ & $\mathrm{n}$ & $\mathrm{n}$ & $\mathrm{n}$ \\
\hline Seeder HORSCH Pronto 6 DC & 83000,00 & 7,50 & $\mathrm{n}$ & $\mathrm{n}$ & $\mathrm{n}$ & $\mathrm{n}$ \\
\hline \multicolumn{3}{|l|}{ Preparation at the same time as sowing } & - & -------- & -------- & ------- \\
\hline Seeder HORSCH - Focus 6 TD & 95000,00 & 5,20 & $\mathrm{n}$ & $\mathrm{n}$ & $\mathrm{n}$ & $\mathrm{n}$ \\
\hline Fertilizer spreader Rauch & 17000,00 & 10,00 & $\mathrm{n}$ & $\mathrm{y}$ & $\mathrm{n}$ & $\mathrm{n}$ \\
\hline \multicolumn{3}{|l|}{ B) Mechanization means for harvesting } & -------- & -------- & -------- & ------- \\
\hline Combine Fendt & 152000,00 & 25,00 & $\mathrm{n}$ & $\mathrm{n}$ & $\mathrm{n}$ & $\mathrm{y}$ \\
\hline 6 line adaptor for maize & 46000,00 & 25,00 & $\mathrm{n}$ & $\mathrm{n}$ & $\mathrm{n}$ & $\mathrm{y}$ \\
\hline Adaptor for rape harvesting & 7000,00 & 25,00 & $\mathrm{n}$ & $\mathrm{n}$ & $\mathrm{n}$ & $\mathrm{y}$ \\
\hline Pea straw crusher & 8000,00 & 25,00 & $\mathrm{n}$ & $\mathrm{n}$ & $\mathrm{n}$ & $\mathrm{y}$ \\
\hline
\end{tabular}

$>$ Overview of the costs of company. It contains an overview of capital and total operating costs of the company (variable and fixed).

$>$ Depreciation. It informs about the annual amount of depreciation of individual types of assets, while it is possible to individually determine the method of depreciation (even or accelerated) and the depreciation period, in accordance with the law.

$>$ Loan, loan repayment. The table calculates the total cost of the investment plan over time. The user decides on the financial coverage through a loan, or newly invested equity or retained earnings from the previous period. The user has the option to choose the amount of the interest rate, the length of the loan deferral period and the form of loan repayment with the same amount of loan repayment or the same amount of total payment.

$>$ Projected statement of profits and losses. This statement is used to calculate the economic result, which is decisive for tax purposes.

$>$ Projected cash flow statement. Information on the net cash flow in individual periods serves as a basis for deciding on the financial coverage of the project in individual time periods and, using the NPV indicator, quantifies the return on equity of the business entity.

\section{$>$ Projected balance sheet.}

\section{Optimization of the structure of plant and animal production}

The basic balance variant is based on the assumption of growing winter wheat on 500 ha, maize on grain 300 ha, oilseed rape 400 ha and peas sown on 300 ha on own land and on leased land of 30 ha of each already mentioned commodity. This variant also includes animal production focused on pig breeding, while the number of litters made is the same in all years, amounting to 60 litters. The investment project itself envisages the procurement of all mechanization means needed for soil preparation, except for the purchase of no-till technology. This particular company does not consider the use of no-till technology in the given conditions.

The scenario of the investment project - in the first year to buy a six-blade plow Vogel - not Hektor 1000 and a seed drill Horsch - Pronto 6 DC, in the second a Rauch industrial fertilizer spreader, in the fourth a Fendt combine with all adapters, can be assessed as attractive based on NPV $185760 €$. The conditions for financial coverage of the investment and the positive value of the cumulative cash flow in each time period are also met. The amount of credit resources in the first year is $€ 125,595$ and in the fourth year $€ 135,329$ to provide mechanization for the initial variant. The terms of the loan are repayments with the same annuity, the interest rate is $6 \%$ and the repayment period is 4 years. 
When adjusting to the optimization model, which aims to optimize the structure of crop production, in addition to the balance sheet conditions, the conditions for securing sources of investment coverage as well as working capital in individual years and conditions for the positive value of cumulative cash flow in each time period were added. In terms of gross profit per hectare, it is most worthwhile to grow oilseed rape and winter wheat. The conditions of the sowing process, the demand for specific production, as well as the reduction of risk through the diversification of crop production are respected across the minimum and maximum limits of representation of individual commodities.

The resulting solution, obtained by optimization (winter wheat on 750 ha, corn 250 ha, oilseed rape 400 ha and peas on 150 ha on own land) requires the same loan in the first year as in the basic balance sheet model, but the loan from the fourth year was reduced to $€ 74,879$. The NPV criterion value is $€ 324,546$, which represents an increase of $€ 138,786$ over the original model. If a restrictive condition for livestock production in pigs is included in a maximum of 80 litters and a minimum of 20 litters, the resulting solution results in a minimum of 20 litters with a corresponding turnover of 14 sows, 147 weaners and 91 fattening pigs. The NPV rose to $€ 365,444$ and the need for credit resources fell to $€ 55,111$ in the fourth year.

\section{Optimal time of acquisition of mechanization tools and optimal loan repayment period}

Mechanization security is one of the key prerequisites for the smooth operation of a business entity in agriculture. The aim of optimization is to identify the way of securing mechanization work - own machines or services, as well as the time of procurement of own machines.

The result of the optimization for the given input parameters is a clear preference for securing mechanization work with our own technology from the first year by purchasing a Vogel plow, a Horsch seed drill, a Rauch industrial fertilizer spreader, as well as a Fendt combine with all adapters. While maintaining the optimal structure of plant and animal production, the NPV will increase to $€ 399,795$ with the amount of credit resources in the first year $€ 355,595$. If the input values change, this can affect the optimal solutions. E.g. if the harvest of maize performed in the form of services would cost less than $70 €$. ha-1, then it is not worth buying an adapter for maize harvesting and the optimal solution in terms of NPV value is to realize the harvesting of maize through services, while increasing the NPV value.

In the case of other additional restrictive conditions relating to limited credit resources of a maximum of $€ 50,000$ each year, the resulting value of the NPV is $€ 340,879$, t. $\mathrm{j}$. a decrease compared to the previous solution by $€ 58,916$. The optimal time of purchase of mechanization means as well as the amount of the loan in the respective year is shown in Table 2. The purchase of machines in the third and fifth year is completely covered from the newly created net income from previous years.

Table 2. Acquisition of mechanization and loan

\begin{tabular}{|c|l|r|}
\hline Year & \multicolumn{1}{|c|}{ Mechanization } & \multicolumn{1}{|c|}{ Loan } \\
\hline 1 & 6 blade plow Vogel-nootHektor 1000 & $42595 €$ \\
\hline 2 & seeder Horch Pronto 6 DC & $31079 €$ \\
\hline 3 & Fertilizer spreader Rauch & $0 €$ \\
\hline 4 & $\begin{array}{l}\text { combine Fendt adaptor for rape harvesting } \\
\text { pea straw crusher }\end{array}$ & $42969 €$ \\
\hline 5 & adaptor for maize harvesting & $0 €$ \\
\hline
\end{tabular}

The implementation of the optimal loan repayment period is based on the results of the Optimization of mechanized security option with a limited loan amount, while the loan conditions are the same as in previous variants, namely repayments with the same annuity, interest rate $6 \%$ and repayment period 4 years. Only the condition of the repayment period of a maximum of 7 years will change. The result of the optimization is that the loan amount in the first two years is the same as in the previous variant, but in the fourth it will increase to $€ 48,284$. The loan from the first year is to be repaid over 4 years, from the second 3 years and from the fourth 7 years. While maintaining the level of interest rates, the value of NPV will increase to $€ 343,922$.

\section{CONCLUSION AND DISCUSION}

The results obtained using the optimization model document the suitability of its use in investment decisions. The purpose function is represented by maximizing assets at the end of the considered period and is in line with the goal of the company's investment policy by creating and implementing investment projects that contribute to growth of the company's market value in the form of net present value. The set of restrictive conditions is represented by the balance of production and financial factors, the balance of cost and production indicators, production and credit restrictions, as well as the conditions of securing the company's liquidity in each time period through positive cumulative cash flow and sufficient financial resources to cover capital investment and working capital. The restrictive conditions respect the economic rules of management of the business entity. The comparison of NPV values documents the logical consequences of individual variants of optimization models and enables the decision-maker to make a decision in accordance with its economic possibilities.

Optimization can be applied in an analogous way in other cases, such as. when identifying the methods of loan repayment (with the same loan repayment or with the same annuity), forms of depreciation (even or accelerated), etc. The created multi-period optimization model represents a suitable support tool for technical, economic, institutional, social 
and environmental analysis of the investment plan, as well as for monitoring in the phase of practical implementation of the investment project and subsequent post audit.

Acknowledgement. The paper is a part of the international project Erasmus+ KA2 Strategic Partnerships Viability of small farms managed by young farmers under new "farm-to-fork" strategy (VISYFARM), solved at the Faculty of Economics and Management, Slovak University of Agriculture in Nitra (Main coordinator: Czech University of Life Science in Prague, Czech Republic).

\section{REFERENCES}

1. Bagui, S. K., Ghosh, A. 2012. Road Project Investment Evaluation Using Net Present Value (NPV) at Risk Method. Jordan Journal of Civil Engineering, Vol. 6(2), pp. 243-254.

2. Baskent, E. Z., Kucuker, D. M., Kadiogullari, A. I. 2011. Getting Various Initial Forest Structures Closer to Optimal Structure by Linear Programming. Kastamonu University Journal of Forestry Faculty, Vol. 11(2), pp. 109-125.

3. Boloș, M. I., Bradea, I. A., Delcea, C. 2020. Linear Programming and Fuzzy Optimization to Substantiate Investment Decisions in Tangible Assets. Entropy, Vol. 22, 121. https://doi.org/10.3390/e22010121

4. Colantoni, A., Villarini, M., Monarca, D., Carlini, M., Mosconi, E. M., Bocci, E., Hamedani S. R. 2021. Economic Analysis and Risk Assessment of Biomass Gasification CHP Systems of Different Sizes through Monte Carlo Simulation. Energy Reports, Vol. 7, pp. 1954-1961. https://doi.org/10.1016/j.egyr.2021.03.028

5. Franco-Sepulveda, G., Campuzano, C., Pineda, C. 2017. NPV risk simulation of an open pit gold mine project under the O'Hara cost model by using Gas. International Journal of Mining Science and Technology, Vol. 27(3), pp. 557-565. https://doi.org/10.1016/j.ijmst.2017.03.004

6. Hopkinson, M. 2016. Net Present Value and Risk Modelling for Projects (1st ed.). Routledge. https://doi.org/10.4324/9781315248172

7. Karahalil, U., Keles, S., Kose, S. 2009. Integrating Soil Conservation, Water Production and Timber Production Values in Forest Management Planning Using Linear Programming. African Journal of Agricultural Research, Vol. 4(11), pp.1241-1250.

8. Kasaš, M., Kravanja, Z, Novak Pintarič, Z. 2011. Suitable Modelling for Process Flow Sheet Optimization Using the Correct Economic Criterion. Industrial \& Engineering Chemistry Research, Vol. 50(6), pp. 3356-3370. https://doi.org/10.1021/ie101485z

9. Khan, A., Asad, M. W. A. 2020. A Mathematical Programming Model for Optimal Cut-off Grade Policy in Open Pit Mining Operations with Multiple Processing Streams. International Journal of Mining Reclamation and Environment, Vol. 34(3) pp.149158. https://doi.org/10.1080/17480930.2018.1532865

10. Lumby, S. 1996. Investment Appraisal and Financial Decisions: 5th edition. London: Chapman \& Hall.

11. Marchioni, A., Magni, C. A. 2018. Investment Decisions and Sensitivity Analysis: NPV-Consistency of Rates of Return. European Journal of Operational Research, Vol. 268, Issue 1, pp. 361-372. https://doi.org/10.1016/i.ejor.2018.01.007

12. McLaney, E. J. 1994. Finance for Decision Makers: London: Pitman Publishing.

13. Norcott, D. 1992. Capital Investment Decision-Making: London: Academic press LTD.

14. Nuryanah, S. 2017. A Financial Optimization Model as a Business Model for Measuring and Managing the Value of Companies: In the Context of Good Corporate Governance (GCG). Proceedings of the 6th International Accounting Conference, Vol. 55, pp. 278-282.

15. Repiský, J. 2006. The evaluation of Investment Strategies Under Risk. In Management Number 44, Year XI December, pp. 36-45. Repiský, J. 2019. Risk Consideration in Investment Plan of Creating a Vineyard. In Ekonomika ta upravlenia APK AIC Economics and Management, No 1, pp. 100-110. https://doi.org/10.33245/2310-9262-2019-148-1-100-110

16. Xu, H. 2015. Using the Net Present Value Rule to Make Value-Creating Investment Decision. In Proceedings of the International Conference on Chemical, Material and Food Engineering, pp. 644-647. https://doi.org/10.2991/cmfe-15.2015.153

17. Žižlavský, O. 2014. Net Present Value Approach: Method for Economic Assessment of Innovation Projects. In Procedia - Social and Behavioural Sciences, Vol. 156, pp. 506-512. https://doi.org/10.1016/j.sbspro.2014.11.230 